\title{
Implications of greenhouse gas emission mitigation scenarios for the main Asian regions
}

\author{
Bas J. van Ruijven ${ }^{\text {a,*}}$, Detlef P. van Vuuren ${ }^{\mathrm{a}, \mathrm{b}}$, Jasper van Vliet ${ }^{\mathrm{a}}$, Angelica Mendoza Beltran ${ }^{\mathrm{a}}$, \\ Sebastiaan Deetman ${ }^{a}$, Michel G.J. den Elzen ${ }^{\text {a }}$ \\ a PBL - Netherlands Environment Assessment Agency, PO Box 1, 3720 BA Bilthoven, The Netherlands \\ b Utrecht University, Department of Geosciences, PO Box 80021, 3508 TA, Utrecht, The Netherlands
}

\section{A R T I C L E I N F O}

\section{Article history:}

Received 1 June 2011

Received in revised form 15 March 2012

Accepted 16 March 2012

Available online 23 March 2012

\section{JEL classification:}

Q40

Q41

Q42

Q54

Q56

Q58

\section{Keywords:}

Greenhouse gas mitigation

Asia

Power sector

Industry

Household fuel switching

Co-benefits

\begin{abstract}
A B S T R A C T
In order to limit global mean temperature increase, long-term greenhouse gas emissions need to be reduced. This paper discusses the implications of greenhouse gas emission reductions for major Asian regions (China, India, Indonesia, South-East Asia, Japan and Korea) based on results from the IMAGE modelling framework. Energy use in regions and economic sectors is affected differently by ambitious climate policies. We find that the potential for emission reduction varies widely between regions. With respect to technology choices in the power sector, we find major application of $\mathrm{CO}_{2}$ storage in Indonesia and India, whereas Korea and India apply more solar and wind. Projections for Japan include a (debatable) large share of nuclear power. China and, India, and South-East Asia, show a diverse technology choice in the power sector. For the industry sector, we find that the recent rapid growth in China limits the potential for emission reduction in the next decades, assuming that recently built coal-based industry facilities are in use for the next decades. For the residential sector, the model results show that fewer households switch from traditional fuels to modern fuels in GHG mitigation scenarios. With respect to co-benefits, we find lower imports of fossil energy in mitigation scenarios and a clear reduction of air pollutant emissions.
\end{abstract}

(c) 2012 Elsevier B.V. All rights reserved.

\section{Introduction}

Limiting global mean temperature increase to only $2-3{ }^{\circ} \mathrm{C}$ with reasonable probability requires major reductions in greenhouse gas emissions (IPCC, 2007). These emission reductions can be achieved with many options, like behavioural change or abatement technologies, such as energy efficiency or renewable energy. Due to differences in historical development, the current energy and economic system, climate and the availability of natural resources technologies play a different role in different geographic regions. Therefore, the potential and costs for emission reduction vary between regions and sectors.

\footnotetext{
* Corresponding author at: National Center for Atmospheric Research (NCAR), P.O. Box 3000, Boulder, CO 80307, USA. Tel.: +1 303497 8387; fax: +1 3034971700. E-mail addresses: vruijven@ucar.edu (B.J. van Ruijven), detlef.vanvuuren@pbl.n (D.P. van Vuuren), jasper.vanvliet@pbl.nl (J. van Vliet), angelica.mendozabeltran@pbl.nl (A. Mendoza Beltran), sebastiaan.deetman@pbl.nl (S. Deetman), michel.denelzen@pbl.nl (M.G.J. den Elzen).
}

Studies show that in the next decades greenhouse gas emissions grow most rapidly in Asia. In 2005, Asia represented 55\% of the global population, $36 \%$ of the global energy-related $\mathrm{CO}_{2}$ emissions and $31 \%$ of global GDP in terms of purchasing power parity (PPP). In the reference scenario of the IMAGE $^{1}$ modelling framework as described in this study, the share of population remains similar towards 2030, but the Asian share in global emissions increases to $50 \%$ and the share of economic activity rises to nearly $45 \%$.

In this paper, we explore the potential for, and implications of emission reduction in several major Asian countries on the basis of the results of the Asian Modelling Exercise (AME) scenarios (see Calvin et al., 2012-this issue) for the IMAGE model. We explore three main questions: 1) what are baseline projections for major Asian countries, 2) what are the implications of GHG mitigation scenarios for the power sector, heavy industry and households, and 3) what are the co-benefits of GHG mitigation for major Asian countries? We

\footnotetext{
${ }^{1}$ Integrated Model to Asses the Global Environment.
} 
focus on six major Asian regions: China,$+{ }^{2}$ India, Japan, Korea, ${ }^{3}$ Indonesia $+{ }^{4}$ and South-East Asia. ${ }^{5}$

This paper is organised as follows. Section 2 describes the IMAGE framework for energy, land use and climate policy. Section 3 presents the reference scenario and GHG emission scenarios for major Asian regions. Section 4 looks closer into the implications of mitigation scenarios for the power sector, heavy industry and household fuel choice. Section 5 explores co-benefits of climate policy for energy trade and air pollutant emissions. Finally, Section 6 discusses the methodology and uncertainties and Section 7 concludes.

\section{Methodology}

\subsection{The IMAGE modelling framework}

For the construction of the scenarios, we use the IMAGE 2.4 Integrated Assessment modelling framework (Bouwman et al., 2006). This framework consists of a set of linked and integrated models that together describe important elements of the long-term dynamics of global environmental change, such as climate change, land use change and air pollution. The global energy model that forms part of the IMAGE model, TIMER ${ }^{6}$ (van Vuuren et al., 2006b), describes the demand and production of primary and secondary energy and the related emissions of greenhouse gases and regional air pollutants. The FAIR-SiMCaP 2.0 model is a combination of the abatement costs model of FAIR and the SiMCaP model (den Elzen et al., 2007). The land and climate modules of IMAGE describe the dynamics of agriculture and natural vegetation, and, together with input from TIMER and FAIR, resulting climate change. The analysis consists of three major steps (van Vuuren et al., 2007, 2010):

1. The reference emission scenario is constructed using the energy (TIMER) and land modules of IMAGE. These models also provide information on the potential emission reduction and associated abatement costs for the energy and land use systems.

2. The FAIR-SiMCaP model is used to develop cost-effective global emission pathways that lead to a long-term concentration target. The FAIR model distributes the global emission reduction from reference to meet the global emission pathway, assuming a cost-optimal implementation of available reduction options over the different regions, gases and sources, using the marginal abatement costs.

3. The energy (TIMER) and land modules of IMAGE implement the changes in emission levels resulting from the abatement action (emission reductions) and the carbon price, as determined in the previous step, to develop the final mitigation scenario (emissions, land use, energy system). Abatement costs of each scenario are calculated based on the marginal carbon prices and the actual reductions. They represent the direct additional costs due to climate policy, but do not capture the macro-economic implications of these costs. We also do not account for (avoided) damages and adaptation costs of climate change.

\subsubsection{Energy}

The IMAGE energy system simulation model (TIMER) describes the long-term dynamics of the production and consumption of 10 primary energy carriers for 5 end-use sectors in 26 world regions (de Vries et al., 2001; van Vuuren et al., 2007). The demand for energy, in most sectors, is derived from changes in useful energy intensity

\footnotetext{
2 Includes China, Hong Kong, Taiwan, Macao and Mongolia.

3 Includes both the Democratic People's Republic of Korea and the Republic of Korea.

4 Includes Indonesia, East Timor and Papua New Guinea.

5 Includes Brunei Darussalam, Lao People's Democratic Republic, Myanmar, Singapore, Viet Nam, Cambodia, Malaysia, Philippines and Thailand.

${ }^{6}$ The model names in this section are acronyms. TIMER = The IMage Energy Regional model; FAIR = Framework to Assess International Regimes for the differentiation of commitments and SiMCaP $=$ Simple Model for Climate Policy Assessment.
}

of economic activity, with autonomous and price-induced energy efficiency increases. Compared to most recent model documentation (van Vuuren et al., 2011), major updates include energy demand modelling in the residential and industry sectors. Residential sector energy demand is based on bottom-up modelling of major end-use functions, household fuel choice, and access to electricity, distinguishing rural/urban households, with each five income classes (Daioglou et al., in review; van Ruijven et al., 2011, 2012). Energy use in the steel and cement sectors is modelled on the basis of per capita consumption projections and competition between production technologies and fuels (Boskaljon, 2010; Neelis and Patel, 2006).

The model's behaviour with respect to energy supply is mainly determined by substitution processes of various technologies based on long-term prices and fuel-preferences. These two factors drive multinomial logit models that describe investments into new energy production and consumption capacity. ${ }^{7}$ The demand for new capacity is limited by the assumption that capital is only replaced after the end of its technical lifetime, which can amount for instance, 40 years for fossil power plants. The long-term prices that drive the model are determined by resource depletion and technology development. Resource depletion is important both for fossil fuels and for renewables (for which depletion and costs depend on annual production rates). Technology development is determined by learning-curves or through exogenous assumptions. Emissions from the energy system are calculated by multiplying energy consumption and production flows with emission factors, based the EDGAR 4.1 database (European Commission Joint Research Centre (JRC)/Netherlands Environmental Assessment Agency (PBL), 2009). A carbon tax can be used to induce a dynamic response such as increased use of low or zero carbon technologies, energy efficiency improvement and end-of-pipe emission reduction technologies.

\subsubsection{Land and climate}

The agricultural model of IMAGE models the productivity of 7 crop groups and 5 animal categories based on the Agro-Ecological Zone (AEZ) approach (Leemans and Born, 1994). Productivity is based on soil conditions, (changing) temperature and precipitation, atmospheric $\mathrm{CO} 2$ concentration and agricultural management (via a regional management factor). Scenarios of agricultural demand, trade and agricultural management are obtained from the LEITAP model (Van Meijl et al., 2006). The regional production of agricultural goods is distributed spatially on the basis of a set of allocation rules (Alcamo et al., 1998). Historical agricultural land cover is calibrated to data from FAO (2007). The potential for bio-energy crop production is based on the assumption that these crops are produced on abandoned agricultural land and natural grasslands only, so do not directly cause deforestation (Hoogwijk et al., 2005). Both changes in land use and agricultural activities are used to model land use-related emissions. The emissions of greenhouse gases and other forcing agents, including tropospheric ozone, sulphur aerosols (negative forcing) and other aerosols are used by the MAGICC 6 model (Meinshausen et al., 2011a, 2011b) included in IMAGE to calculate global mean temperature change. Finally, temperature changes at $0.5 \times 0.5$ degree are obtained using pattern-scaling approaches on the basis of the outcomes of complex climate models (Carter et al., 1994; Schlesinger et al., 2000).

\subsubsection{Climate policy}

The climate policy model FAIR (den Elzen et al., 2007) is used to determine the reduction rates across different emission sources, regions and gases. The SiMCaP pathfinder module makes use of an iterative procedure to find multi-gas emission paths that minimize integrated discounted mitigation costs for the period 2010-2100 (using a constant discount rate of $5 \%$ ), and satisfy a predefined

\footnotetext{
${ }^{7}$ A multinomial logit model assigns market shares to fuel or technologies based on their relative costs. Low costs options get a large market share; high costs options a low (or even zero) market share.
} 
Table 1

Key-assumptions in the IMAGE reference scenario on population, urbanisation and development of GDP per capita.

\begin{tabular}{|c|c|c|c|c|c|c|c|c|}
\hline & & World & China + & India & Japan & Korea & Indonesia + & South-East Asia \\
\hline \multirow[t]{3}{*}{ Population (million persons) } & 2005 & 6531 & 1345 & 1131 & 127 & 71 & 225 & 335 \\
\hline & 2020 & 7691 & 1467 & 1367 & 124 & 74 & 261 & 399 \\
\hline & 2050 & 9154 & 1454 & 1614 & 102 & 66 & 296 & 478 \\
\hline \multirow{3}{*}{$\begin{array}{l}\text { Urbanisation (percentage urban } \\
\text { population in total population) }\end{array}$} & 2005 & $49 \%$ & $41 \%$ & $29 \%$ & $66 \%$ & $74 \%$ & $47 \%$ & $41 \%$ \\
\hline & 2020 & $55 \%$ & $53 \%$ & $34 \%$ & $69 \%$ & $79 \%$ & $61 \%$ & $51 \%$ \\
\hline & 2050 & $70 \%$ & $73 \%$ & $55 \%$ & $80 \%$ & $86 \%$ & $77 \%$ & $70 \%$ \\
\hline \multirow[t]{3}{*}{ GDP per capita (PPP, int $\$ 2005 / y r)$} & 2005 & 8791 & 5106 & 2154 & 30387 & 15767 & 3176 & 4336 \\
\hline & 2020 & 12830 & 14303 & 5218 & 37392 & 25988 & 5935 & 6836 \\
\hline & 2050 & 28044 & 39238 & 20477 & 63569 & 46411 & 18083 & 19823 \\
\hline \multirow[t]{3}{*}{ GDP per Capita (MER, USD $2005 / \mathrm{yr}$ ) } & 2005 & 6967 & 2221 & 717 & 35717 & 12146 & 1291 & 1832 \\
\hline & 2020 & 9375 & 7186 & 1975 & 44806 & 21318 & 2612 & 3068 \\
\hline & 2050 & 19836 & 22841 & 9944 & 76973 & 39015 & 9502 & 10473 \\
\hline
\end{tabular}

climate target. Global climate calculations make use of the simple climate model, MAGICC 6.3 (Meinshausen et al., 2011a, 2011b). The FAIR cost model distributes the required emission reductions from baseline among the regions following a least-cost approach using regional marginal abatement costs curves (MACs) for the different emissions sources (den Elzen et al., 2008). The emission reduction potential for $\mathrm{CO}_{2}$ emissions from the energy sector are derived from the TIMER model (van Vuuren et al., 2006b), the emission reductions by reforestation activities and the non- $\mathrm{CO}_{2}$ greenhouse gas reductions on scaled marginal abatement curves (Lucas et al., 2007).

\subsection{Mitigation scenario design}

In this paper, we look at the 6 scenarios that were used in the Asian Modelling Exercise (Calvin et al., 2012-this issue):

- The reference scenario (depicting developments in the absence of climate policy)

- three carbon price-path scenarios (looking into the model response for standardized price pathways)

- and two stabilisation scenarios for $3.7 \mathrm{~W} / \mathrm{m}^{2}$ and $2.6 \mathrm{~W} / \mathrm{m}^{2}$.

\subsubsection{Reference scenario}

The reference scenario for the IMAGE scenario set for the AME is recently developed for the OECD Environment Outlook (OECD, 2011). This scenario can be characterised as business as usual scenario, without new policies and without major changes in preferences or behaviour. Population projections are based on the UN population prospects (UN Population Division, 2010), with global population increasing to 7.7 billion in 2020 and almost 9.2 billion in 2050. The global average urbanisation ratio increases from about 50\% today, to $55 \%$ in 2020 and $70 \%$ in 2050 . The economic projections, obtained from the OECD ENV-linkages model, are used as drivers to produce the detailed physically oriented projections for the energy and land use sectors. World economic product grows with an average 3.7\% per year between 2005 and 2020, and an average 3.25\% per year in the period 2020-2050. In terms of energy use, this scenario is calibrated to the IEA World Energy Outlook projections until 2030 (IEA, 2009), following a similar business as usual pattern in the period 2030-2050.

Population in the major Asian regions in the reference scenario is expected to increase continuously in India, Indonesia and South-East Asia, slower growth in China and a reduction of population in Japan, later followed by Korea (Table 1). Urbanisation increases steadily, Japan and Korea reach over $80 \%$ urban population in 2050 , with China, Indonesia and South-East Asia following suit. India has a clearly lower urbanisation rates. With respect to economic activity, (expressed in PPP), China is projected to reach the present-day Japanese level of GDP per capita in 2040, while India, Indonesia and South-East Asia surpass present-day levels of Korea by 2050.

\subsubsection{Price-path scenarios}

The three price pathway scenarios describe developments under prices that start at 10,30 and $50 \mathrm{USD} / \mathrm{tCO}_{2}$ in 2020 and increase with $5 \%$ per year afterwards. These scenarios are called resp. " $\mathrm{CO}_{2}$ Price $\$ 10$ (5\% p.a.)", " $\mathrm{CO}_{2}$ Price $\$ 30$ (5\% p.a.)" and " $\mathrm{CO}_{2}$ Price $\$ 50$ (5\% p.a.)" (see Table 2 ).

\subsubsection{Stabilisation scenarios}

Next to the price pathway scenarios, two mitigation scenarios have been run that aim for specific climate stabilisation targets. The "3.7 W/m $/ \mathrm{m}^{2}$ " not-to exceed (NTE) scenario was run for the standard set of technologies, (as were the price-path scenarios), which does not include the option of bio-energy with carbon-capture and storage (BECCS). For the " $2.6 \mathrm{~W} / \mathrm{m}^{2}$ " scenario with overshoot allowed (OS), BECCS was included. BECCS results in net-negative emissions, as carbon is first taken up by vegetation and consequently captured and sequestrated. This leads to more emission reduction at lower costs, and a different distribution of emission reductions over regions, related to the regional potential for carbon storage. We choose to exclude BECCS from the standard set of technologies because it is an uncertain technology that combines two technologies whose individual potential is debated: bio-energy and CCS. However, the " $2.6 \mathrm{~W} / \mathrm{m}^{2}$ OS" target is not attainable in our model with the application of BECCS.

In the remainder of this paper, we focus primarily on the reference scenario and the "2.6 W/m² $\mathrm{m}^{2}$ " scenario, to show the range of impacts and co-benefits of GHG mitigation in Asia. The full range of scenario results is available in the online database of the Asian Modelling Exercise (reference to be added)

\section{Results for energy and $\mathrm{CO}_{2}$ projections}

\subsection{Energy projections}

Global primary energy use in the reference scenario increases from $490 \mathrm{EJ} / \mathrm{yr}$ in 2005 to $625 \mathrm{EJ} / \mathrm{yr}$ in 2020 and $850 \mathrm{EJ} / \mathrm{yr}$ in 2050 (Fig. 1). In the reference scenario, energy use in the Asian regions increases considerably. Chinese primary energy use almost doubles between 2005 and 2020, increasing to over $170 \mathrm{EJ} / \mathrm{yr}$ in 2050. India

Table 2

Carbon prices (in $\mathrm{USD}_{2005} / \mathrm{tCO}_{2}$ ) in the IMAGE scenarios for the AME. Note that the "2.6 W/ $\mathrm{m}^{2}$ OS" contains bio-energy-with-CCS technology, enabling more emission reductions at similar costs.

\begin{tabular}{llccrr}
\hline & 2010 & 2020 & 2030 & 2040 & 2050 \\
\hline Reference & 0 & 0 & 0 & 0 & 0 \\
$\mathrm{CO}_{2}$ price $\$ 10$ (5\% p.a.) & 0 & 10 & 16 & 27 & 43 \\
$\mathrm{CO}_{2}$ price $\$ 30$ (5\% p.a.) & 0 & 30 & 49 & 80 & 130 \\
$\mathrm{CO}_{2}$ price $\$ 50$ (5\% p.a.) & 0 & 50 & 81 & 133 & 216 \\
$3.7 \mathrm{~W} / \mathrm{m}^{2}$ not-to-exceed (NTE) & 0 & 24 & 49 & 58 & 59 \\
$2.6 \mathrm{~W} / \mathrm{m}^{2}$ overshoot (OS) & 0 & 43 & 63 & 79 & 105 \\
\hline
\end{tabular}




$\begin{array}{lll}\square \text { Coal } & \square \text { Oil } & \square \text { N.Gas } \\ \square \text { Mod.Bio } & \square \text { Coal+CCS } & \square \text { Oil+CCS } \\ \square \text { N.Gas+CCS } & \square \text { Bio+CCS } & \square \text { Trad.Bio } \\ \square \text { Nuclear } & \square \text { Solar Thermal } & \square \text { Solar PV } \\ \square \text { Wind } & \square \text { Other renewable } & \square \text { Hydro }\end{array}$
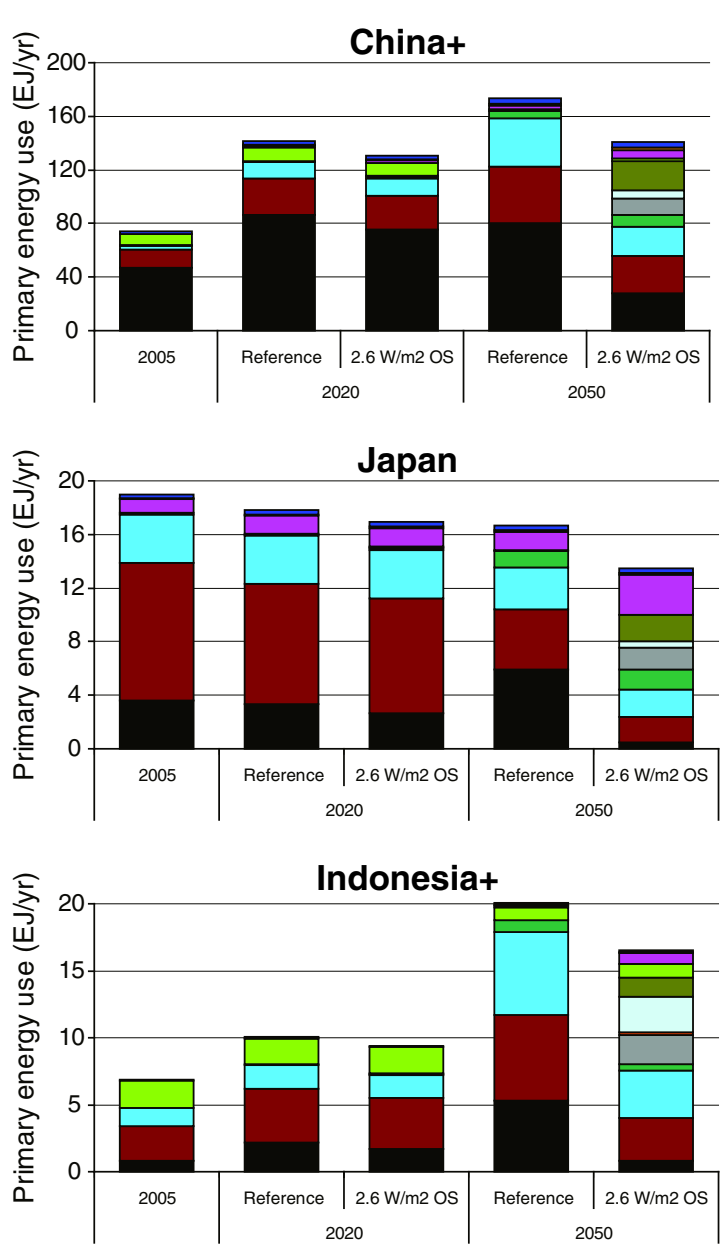
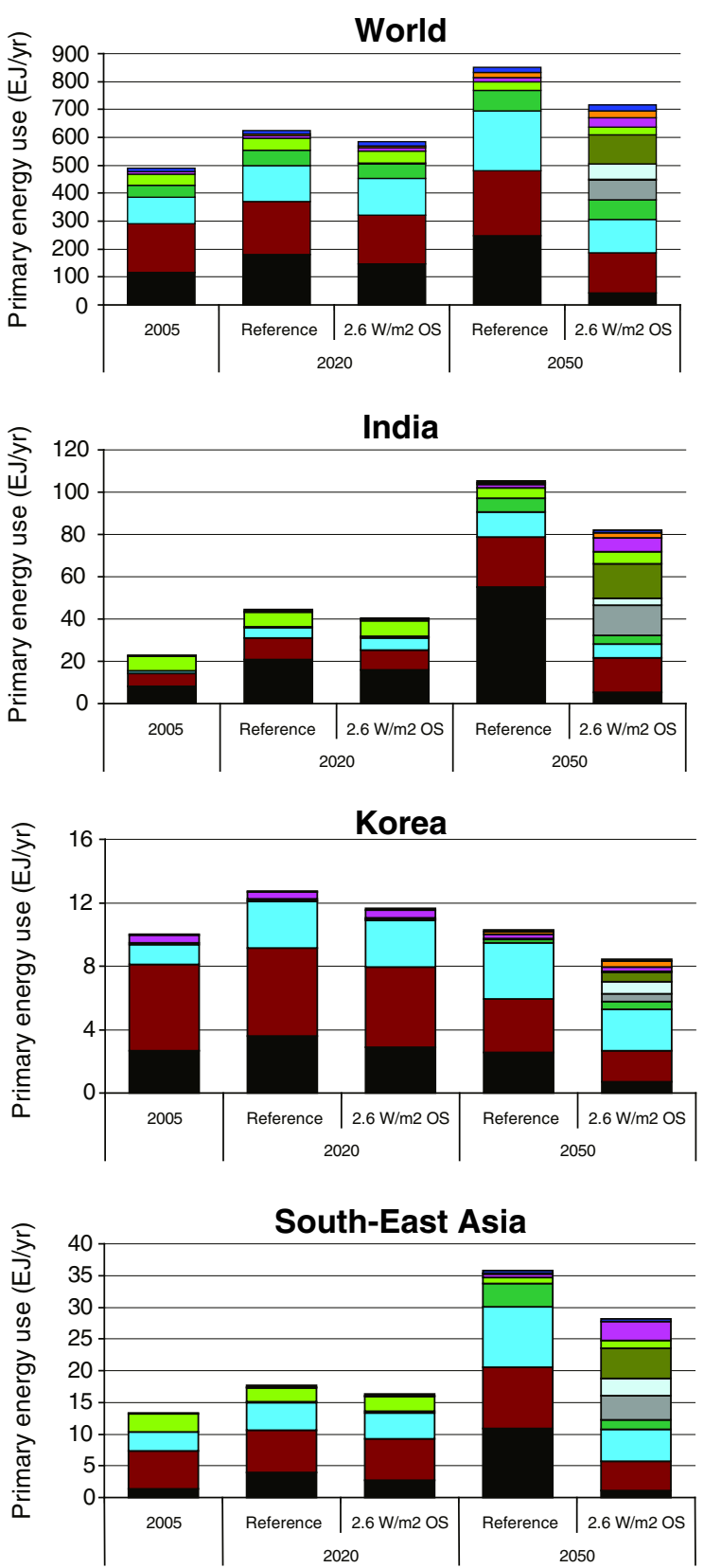

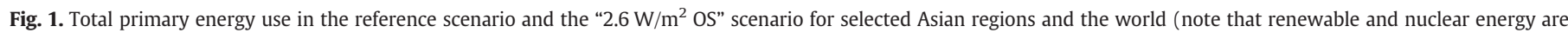
shown in direct equivalent of produced electricity).

faces rapid growth in energy use after 2020, more than doubling from 45 to $105 \mathrm{EJ} / \mathrm{yr}$ between 2020 and 2050. Both Chinese and Indian primary energy use are dominated by coal, complimented by rapidly increasing oil due to growth in the transport sector and gas in electricity production and households. Indonesia and South-East Asia show similar high-growth patterns of energy use, but are less dominated by coal, with a bigger role for oil and natural gas. The level of total primary energy use in Japan and Korea follows the population projections: decreasing slowly in Japan, and peaking around 2025 in Korea. In Japan, an increase in oil prices in the reference scenario causes a phase out of oil in electricity production, being replaced by coal (see Section 3.1 and Fig. 3).

In the "2.6 W/m² OS" scenario, primary energy use is reduced, both globally and in individual regions, as result of increased energy efficiency. For 2020 the fuel mix is somewhat similar as the reference scenario, but with slightly less coal and more natural gas and nuclear. In 2050, primary energy use under the " $2.6 \mathrm{~W} / \mathrm{m}^{2}$ OS" scenario has completely changed, compared to the reference scenario. The use of fossil fuels has been reduced, bio-energy-with-CCS has gained importance, as have renewable, nuclear and fossil energy with CCS.

\subsection{Greenhouse gas emissions and mitigation in the AME scenarios}

Global GHG emissions increase from $45.9 \mathrm{Gt} \mathrm{CO}_{2}$-eq/yr in 2005 to $53.7 \mathrm{Gt} \mathrm{CO}-\mathrm{eq} / \mathrm{yr}$ in 2020 and $58.3 \mathrm{Gt} \mathrm{CO}_{2}$-eq/yr in 2050 (Fig. 2). As projections of GHG emissions are closely related to projections of energy use, the projections in the reference scenario follow a similar pattern as primary energy use for the individual regions. China is expected to maintain the rapid growth of GHG emissions until 2040. After 2040, emissions are projected to peak at about $14 \mathrm{Gt}$ $\mathrm{CO}_{2}$-eq/yr. This is over $25 \%$ of global emissions at that time. Indian GHG emissions continue to grow to over $8 \mathrm{Gt} \mathrm{CO}_{2}$-eq/yr in 2050 . The same pattern of steady growth holds for Indonesia and SouthEast Asia. Korean emissions, in contrast, are expected to peak 

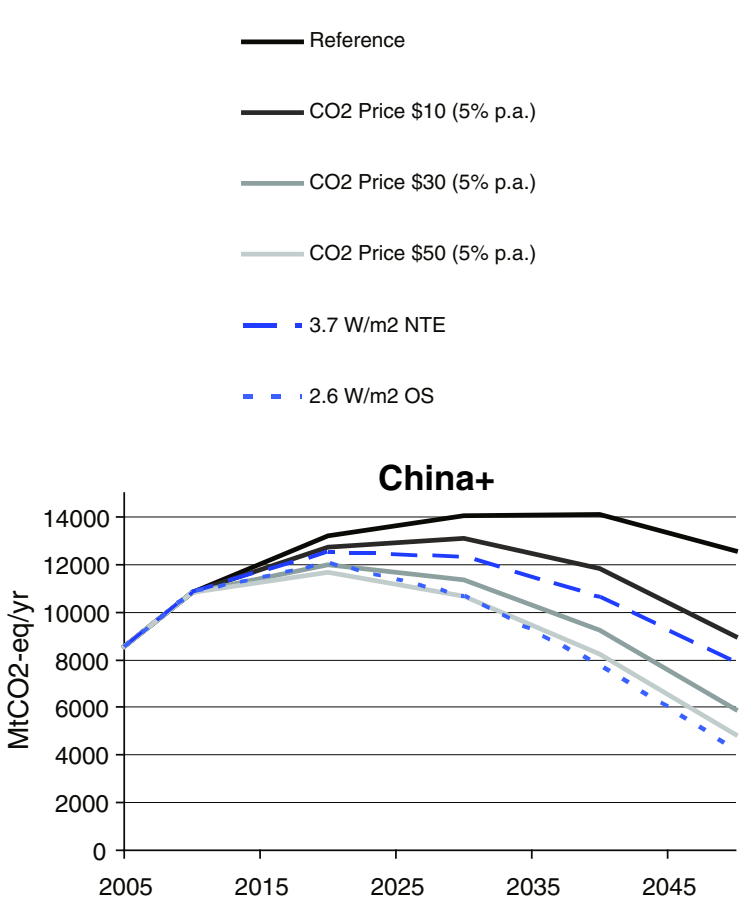

Japan

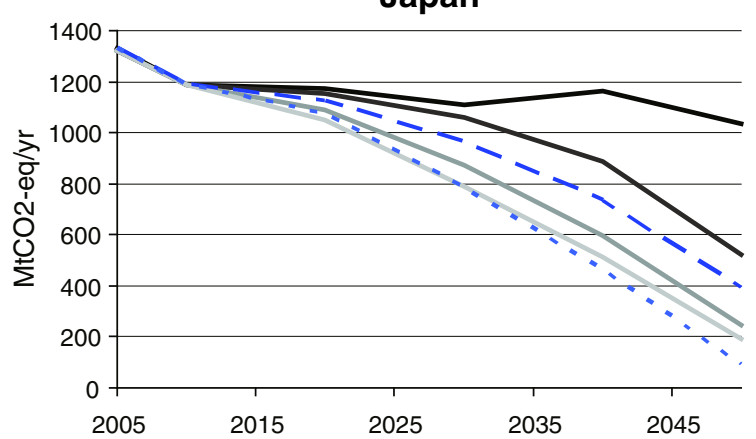

Indonesia+

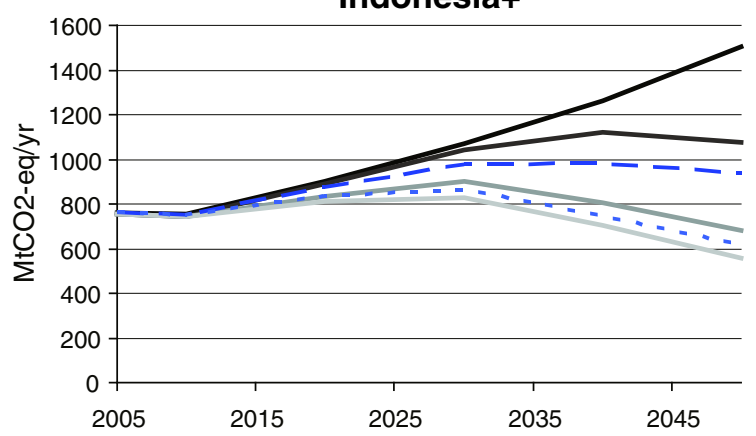

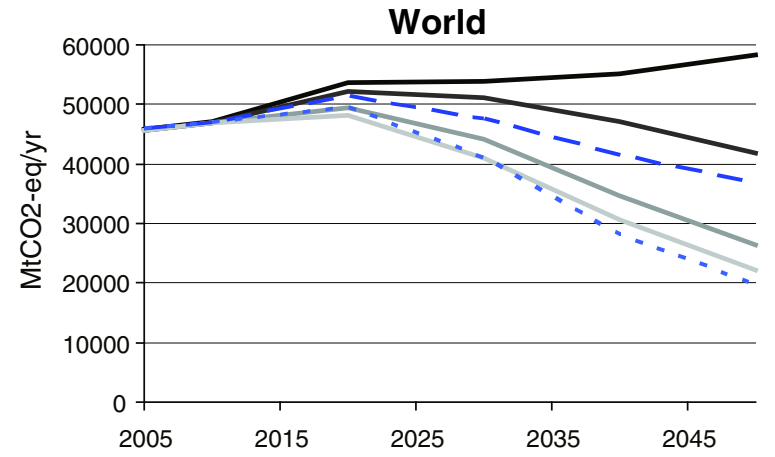

India

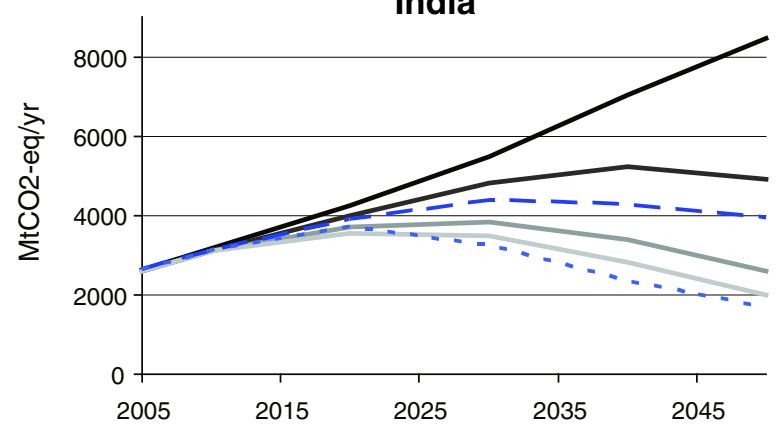

Korea

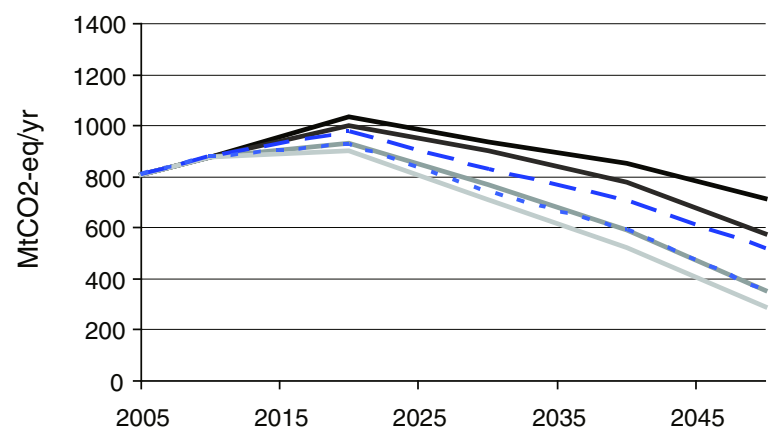

South-East Asia

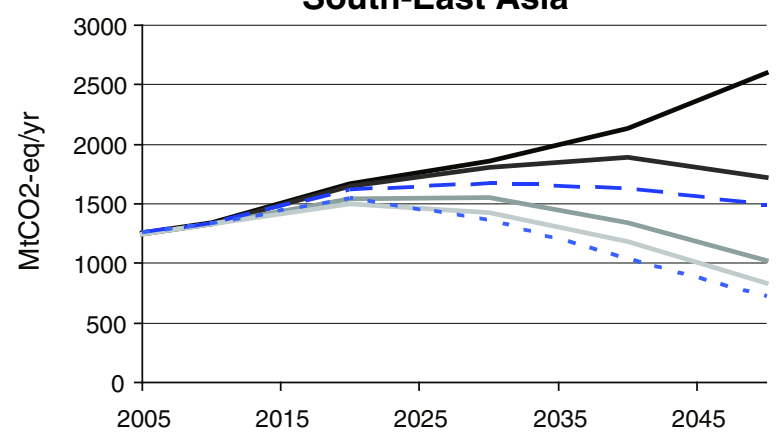

Fig. 2. Total greenhouse gas emission emissions from in the AME scenarios for selected Asian regions and the world.

between 2020 and 2025 (as its energy use). Japanese emissions remain stable, contrary to the decreasing primary energy use. This is due to an increasing share of coal, replacing oil in the power sector as result of increasing oil prices.

The mitigation scenarios result in different $\mathrm{CO}_{2}$ emission reductions. Looking first at the price-path scenarios (depicted in grey in Fig. 2), a major emission reduction compared to the reference scenario can be seen in India, Japan, Indonesia and South-East Asia. Korea has less reduction compared to its (already decreasing) reference scenario. Chinese reductions take place mainly after 2030.
Towards the higher tax scenarios, India and Indonesia reduce emissions in 2050 to their 2005 levels, whereas China and South-East show a peak first, but reduce emissions below their 2005 levels in 2050. Japan and Korea reduce their emissions in 2050 with resp. $80 \%$ and $70 \%$ compared to their 2005 levels, in the high carbon price scenario.

The "3.7 W/m² NTE" stabilisation scenario leads to an emissions pathway between the 10 and $30 \$$ carbon price pathways, in line with the carbon value in these scenarios (Table 1). The emissions associated with the " $2.6 \mathrm{~W} / \mathrm{m}^{2}$ OS" scenario correspond to a trajectory 
slightly below the $50 \$$ price pathway (again see also Table 1 for the carbon prices).

\section{Implications of emission reduction for sectors and regions}

\subsection{Asian power sector and greenhouse gas mitigation}

The power sector plays a key role in future energy use and mitigation of greenhouse gas emissions. It accounts globally for one third of energy-related $\mathrm{CO}_{2}$ emissions and is related to both the consumption of energy and choices with respect to (centralised) production.

In the reference scenario, the electricity production (Fig. 3) follows a similar pattern as primary energy use projections (Fig. 1). It shows continuing rapid growth in India and China, both dominated by coal, though with an increasing share of natural gas. Japan shows a slow increase in the consumption of electricity the reference scenario, but in power production oil is being replaced by coal power plants. Korea shows a slow growth in electricity use, with a slight shift to natural gas and solar/wind in the reference scenario. Indonesia shows major growth and is dominated by coal and natural gas. Projections for South-East Asia follow a similar pattern, with major growth and dominance of coal and natural gas, but with a larger role of bio-energy.

The " $2.6 \mathrm{~W} / \mathrm{m}^{2}$ OS" scenario shows for 2020 a somewhat similar fuel mix as the reference scenario, but with less coal and more natural gas and nuclear. By 2050, however, the results of the " $2.6 \mathrm{~W} / \mathrm{m}^{2}$ OS" are completely different, as the whole power sector has changed under the climate regime. By that time, bio-energy-with-CCS is clearly important in all regions. In China, electricity production from coal is reduced to present-day levels in 2050 under the " $2.6 \mathrm{~W} / \mathrm{m}^{2}$ OS" scenario, and it is replaced by natural gas, bio-energy, nuclear and solar/wind. Indian power production is almost fully emission-free in 2050, from a combination of coal-with-CCS, bio-energy-with-CCS, a large share of nuclear and some solar/wind. Whereas Japan is rather dominated by coal in the reference scenario, in the " $2.6 \mathrm{~W} / \mathrm{m}^{2}$ OS" scenario fossil fuels are completely phased out and replaced by nuclear power production and bio-energy-with-CCS (see also further). Korea shows a diversified pattern, some fossil energy sources, some bio-energy and solar/wind. The same holds for Indonesia and SouthEast Asia, the first being dominated more by CCS, the second more by nuclear.

The difference in power production between the regions can be mainly explained from two dynamics: 1) vintage stock turnover of production capacity and 2) potential/costs for alternative technologies.

With respect to the first, electricity production capacity is only replaced at the end of its technical lifetime and investments are made without any forward-looking behaviour. In the rapidly growing Asian regions, the outline of the power system in 2050 is very much determined by the optimal technology choice at the time that rapid growth takes place. For instance, the growth in Chinese power production has mainly taken place in the past 10 years and is expected to remain until 2030, expanding its capacity of fossil power plants
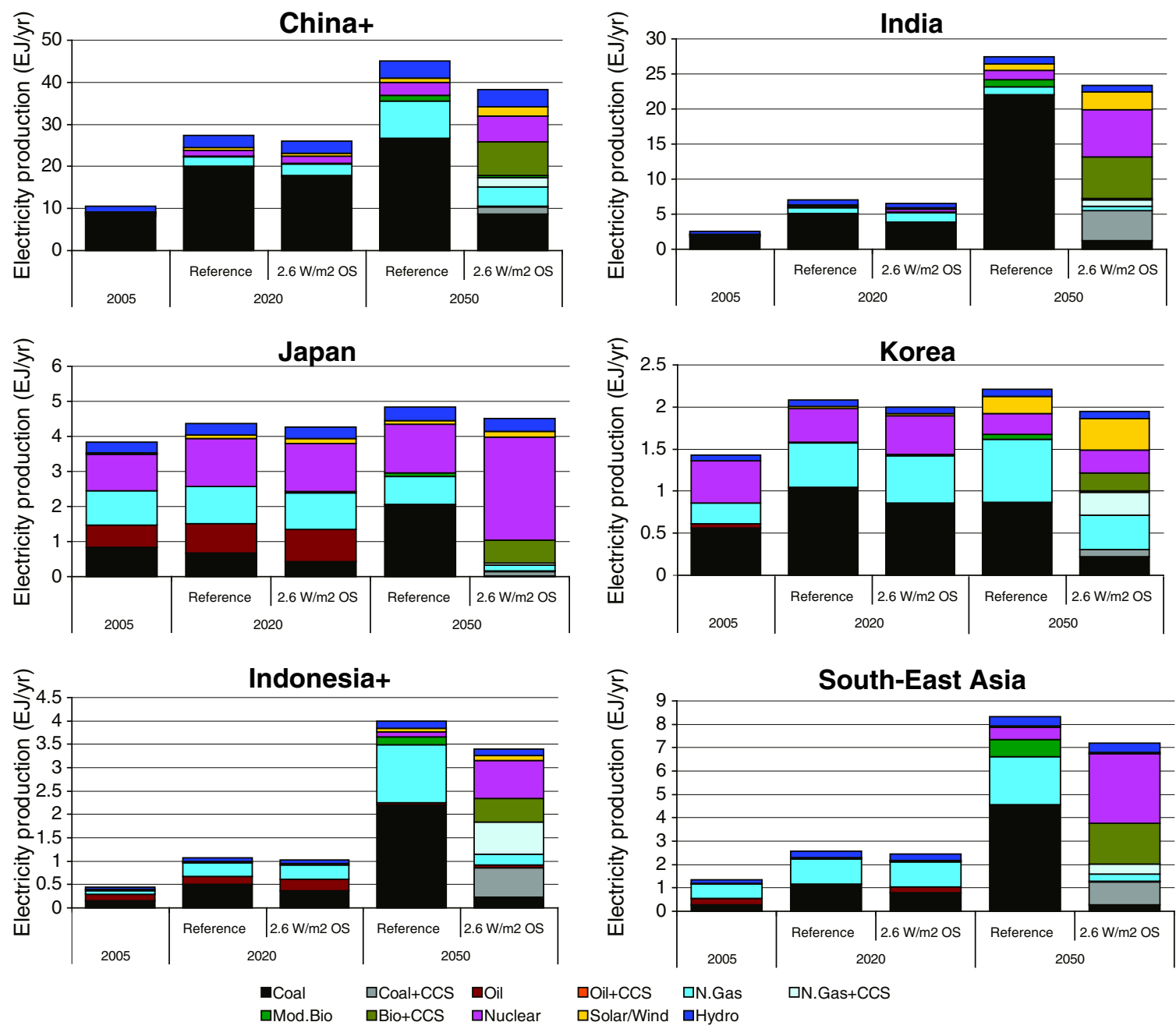

$\square$ Oil+CCS $\quad$ aN.Gas $\quad$ N.Gas+CCS

Fig. 3. Electricity production in the reference scenario and the " $2.6 \mathrm{~W} / \mathrm{m}^{2}$ OS" scenario. 
(as these have the lowest costs). As result, China still has a large share of conventional coal power plant in the " $2.6 \mathrm{~W} / \mathrm{m}^{2}$ OS" scenario in 2050. The rapid growth phase in India takes place after 2020, when carbon prices in the scenario are higher and low-emission technologies become relatively more attractive. As a result, Indian power production is almost without $\mathrm{CO}_{2}$ emission in the " $2.6 \mathrm{~W} / \mathrm{m}^{2}$ OS" scenario.

The second cause of differences between regions is related to costs of low-emission technologies. In some regions, like Indonesia and India, storage capacity for $\mathrm{CO}_{2}$ is attractively available. Other regions have rather low-cost potentials for solar/wind, like Korea or India. Japan is a typical region, with a lack of endogenous resources and alternatives, and a related historic preference for nuclear power (although recent incidents in the Fukushima plant may lead to important changes here).

\subsection{Heavy industry and the impact of recent economic growth on mitiga- tion potential}

Another major energy consuming sector is the industry sector, globally accounting for about $20 \%$ of energy-related $\mathrm{CO}_{2}$ emissions. In this sector, the implications of the vintage stock dynamics become even more distinct than in the power sector.

In China, the industry sector has been a major driver of rapid emissions growth. To explore the impact of the recent high economic growth in China on its mitigation potential, we compare the steel production in China and India. As Fig. 4 shows, Chinese steel production increased from 140 Mt crude steel in 2000 to over 500 Mt in 2007. The largest contributor to this increase was a four-fold increase of coal-based blast furnaces. For the near future, this growth is projected to continue. Given an assumed average lifetime of 30 years, a large share of the recently built steel production capacity is likely to be still operational in 2020 and 2030 . Hence, the options for mitigation, like investments in efficient blast furnaces or electric arc steel production, are likely to be limited by a lack of demand for new steel facilities in the coming decades. Retrofitting and early retirement of plants are alternatives that would increase mitigation capacity. However, the reduction potential for retrofitting from standard coal blast furnaces is limited, and early retirement would be a decision of individual investors to take their losses.

For India, this situation is completely different, as a major growth in steel production is projected to take place towards 2020 and 2030. Already in the reference scenario, efficient blast furnaces and electric arc steel plants are preferred over standard coal-based facilities. In the " $2.6 \mathrm{~W} / \mathrm{m}^{2}$ OS" scenario, Indian steel production in 2030 is for more than $25 \%$ based on CCS technology, whereas in China, this is limited to $5 \%$. On the longer term, a complete turnover of the steel production stock is expected in both regions by 2050. And hence, the limitations that result from the stock dynamics will disappear towards 2050.

\subsection{Implications of climate policy for households}

Another sector that is influenced by climate policy is the household sector. Especially in developing countries with a large share of low income population, the household sector represents an important source of emissions (Daioglou et al., in review). A general pattern in household energy use is the energy ladder, where households switch from traditional fuels (fuelwood or dung) to cleaner fuels (kerosene, LPG, electricity) when their welfare level increases (Hosier and Dowd, 1987; Reddy and Reddy, 1994; van Ruijven et al., 2008). We modelled the fuel choice of households on the basis of two counteracting forces: first, increasing capital availability if a household grows wealthier, allowing it to choose more capital intensive and cleaner fuel types; secondly, wealthier households pay more attention for the disadvantages of traditional fuels (indoor air pollution, time consumption) (Ekholm et al., 2010; van Ruijven, 2008; van Ruijven et al., 2011). Both forces evolve dynamically with the income level of the household, and as a result, fuel choices change over time as income is projected to increase.

It should be noted that there is a potential trade-off between climate policy and indoor air quality. The reason is that the choice between fuels, including the switch from traditional (solid) fuels to clean fuels, depends in our model on the mutual cost difference between the fuels. Hence, if a climate policy is introduced, and fossil fuels (like LPG or kerosene) become more expensive, fewer households switch to these cleaner fuels. This dynamic is shown in Table 3: the share of (total and rural) population using solid fuels in the reference scenario and the " $2.6 \mathrm{~W} / \mathrm{m}^{2}$ OS" scenario. The results show that, although the population using solid fuel decreases steadily over time, this decrease is much lower in the " $2.6 \mathrm{~W} / \mathrm{m}^{2}$ OS" scenario than in the reference scenario. The difference between the two scenarios, can amount to as much as 14 percent-points in rural India in 2050, representing over 100 million people in absolute terms. Off course, this trade-off of climate policy could be undone by the introduction of targeted subsidies on LPG or electricity, though this comes at potentially high costs and uncertain efficacy of subsidies.

\section{Co-benefits of mitigation}

\subsection{Energy security}

A potential co-benefit of climate policy is that the decreased use of fossil fuels could also lead to a reduced import of fossil fuels. Many
China+

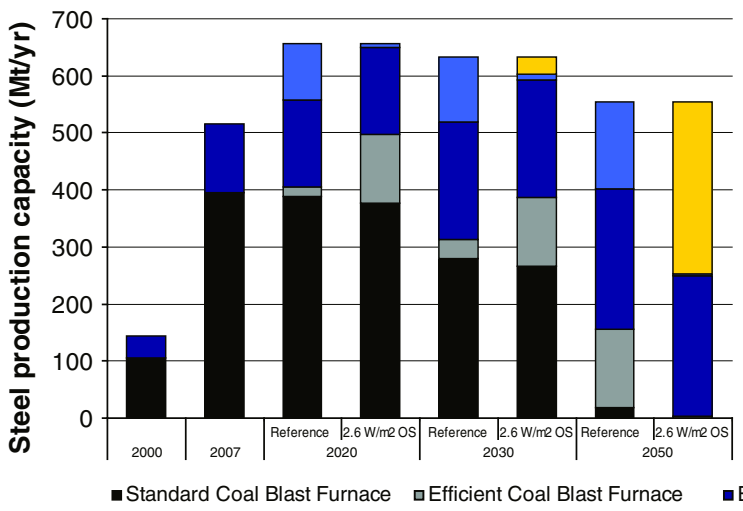

India

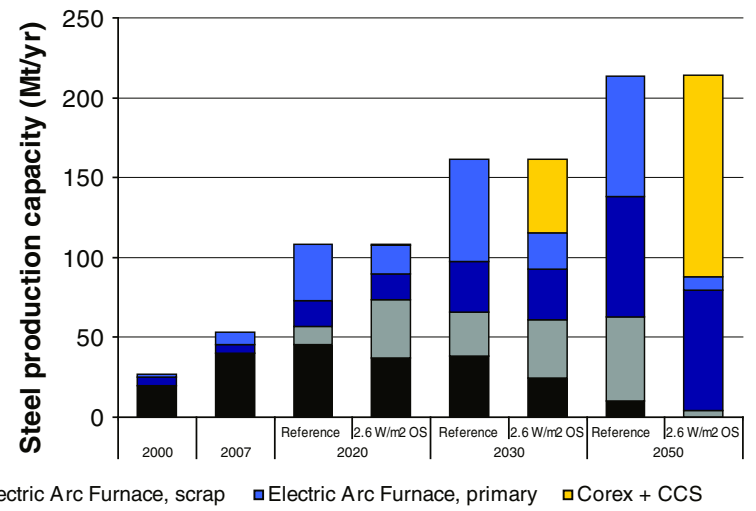

Fig. 4. Steel production capacity in China and India in the reference scenario and the " $2.6 \mathrm{~W} / \mathrm{m}^{2}$ OS" scenario. 
Table 3

Percentage population using solid fuels in China and India in the reference scenario and the " $2.6 \mathrm{~W} / \mathrm{m}^{2}$ OS" scenario.

\begin{tabular}{|c|c|c|c|c|c|c|c|}
\hline & & \multicolumn{3}{|c|}{ Percentage of total population using solid fuels } & \multicolumn{3}{|c|}{ Percentage of rural population using solid fuels } \\
\hline & & $2005(\%)$ & $2020(\%)$ & $2050(\%)$ & $2005(\%)$ & $2020(\%)$ & $2050(\%)$ \\
\hline \multirow[t]{2}{*}{ China +} & Reference & 65 & 44 & 14 & 91 & 79 & 43 \\
\hline & $2.6 \mathrm{~W} / \mathrm{m} 2 \mathrm{OS}$ & & 42 & 17 & & 80 & 53 \\
\hline \multirow[t]{2}{*}{ India } & Reference & 74 & 65 & 23 & 93 & 92 & 47 \\
\hline & $2.6 \mathrm{~W} / \mathrm{m} 2 \mathrm{OS}$ & & 67 & 30 & & 94 & 61 \\
\hline \multirow[t]{2}{*}{ Indonesia +} & Reference & 53 & 45 & 19 & 88 & 93 & 72 \\
\hline & $2.6 \mathrm{~W} / \mathrm{m} 2 \mathrm{OS}$ & & 46 & 21 & & 93 & 79 \\
\hline \multirow[t]{2}{*}{ South-East Asia } & Reference & 73 & 49 & 15 & 87 & 64 & 26 \\
\hline & $2.6 \mathrm{~W} / \mathrm{m} 2$ os & & 50 & 20 & & 66 & 36 \\
\hline
\end{tabular}

countries do interpret this as an increase in energy security. Since most Asian regions are major energy importers (or are expected to become so in the next decades), this is a very relevant issue. Fig. 5 shows energy trade in the reference and " $2.6 \mathrm{~W} / \mathrm{m}^{2}$ OS" scenarios and. Table 4 depicts these trade flows relative to primary energy use in the regions. It shows that, under the reference scenario, China is projected to import large flows of fossil fuels towards 2050. These flows account for $33 \%$ of its coal use, and almost all its demand for oil and natural gas. In the " $2.6 \mathrm{~W} / \mathrm{m}^{2}$ OS" scenario, the absolute imports of fossil energy are reduced by about $30 \%$ (Fig. 5). Particularly coal import is reduced significantly, though partly replaced with increased import of bio-energy.
India is heavily dependent on oil imports in both the reference scenario (100\% of total oil use in 2050) and the " $2.6 \mathrm{~W} / \mathrm{m}^{2}$ OS" scenario (97\%) (Table 4). However, absolute oil imports are about 40\% lower in the climate policy scenario (Fig. 5), and a large part of this decrease is replaced with imports of bio-energy.

Energy imports for Japan decrease in the reference scenario, the pattern of replacing oil with coal in the power sector can be observed in imports as well. In the " $2.6 \mathrm{~W} / \mathrm{m}^{2}$ OS" scenario absolute imports of fossil energy to Japan decrease further towards 2050 (Fig. 5). However, imports still account for all its use of fossil energy and bio-energy (Table 4). Korea and South-East Asia show a similar pattern, falling
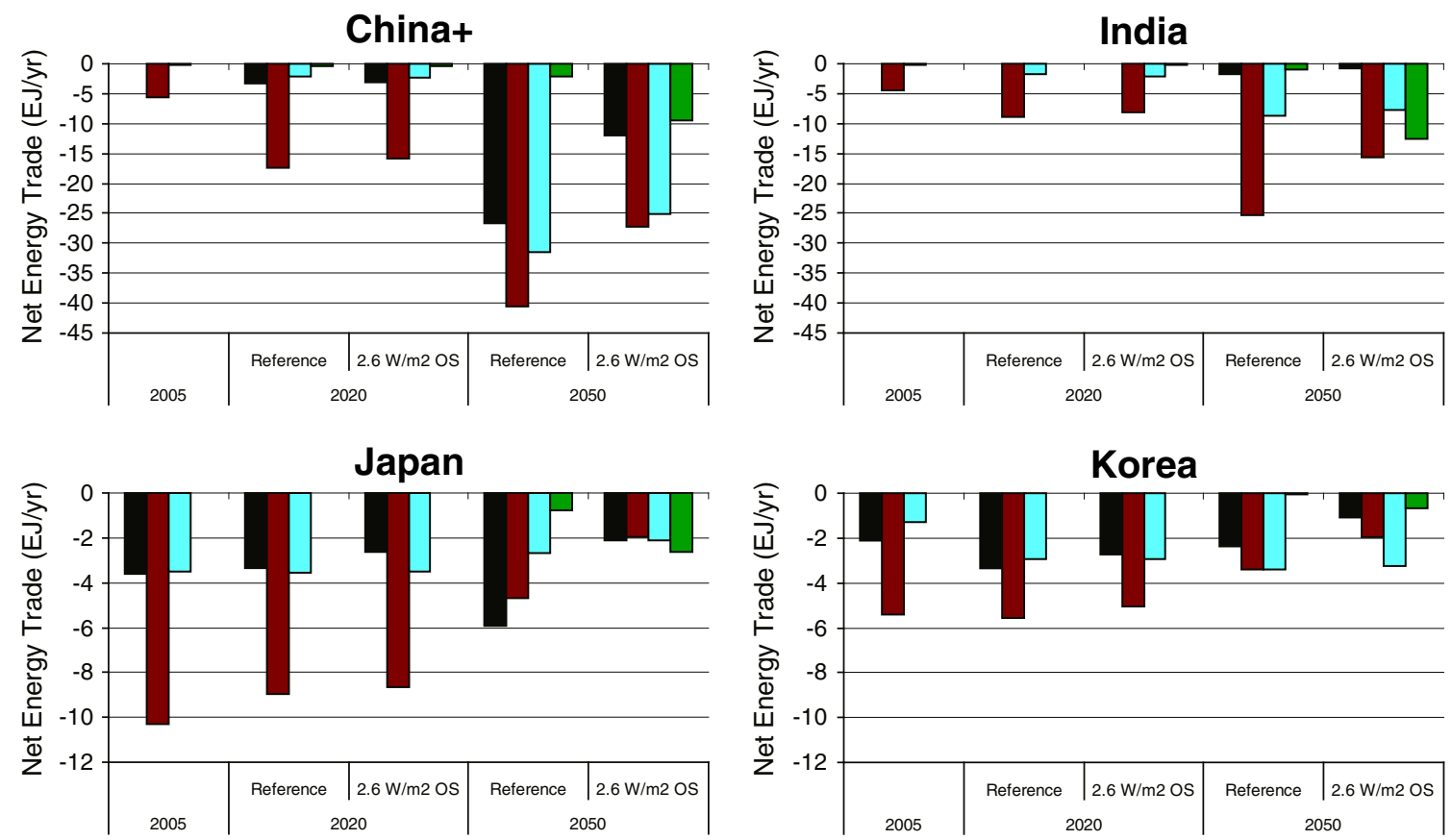

Indonesia+
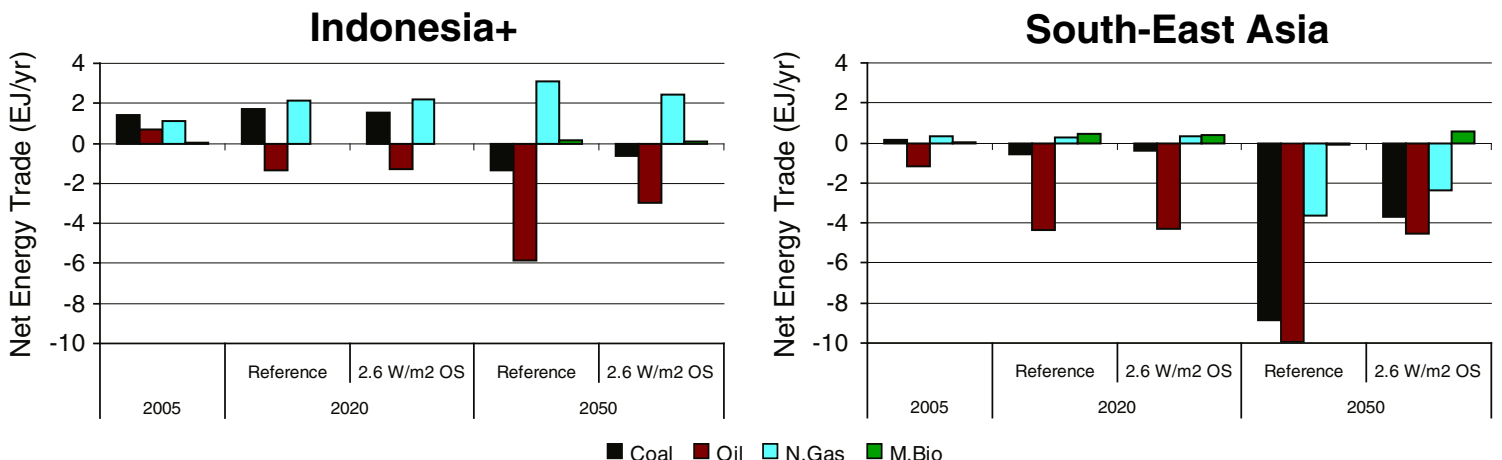

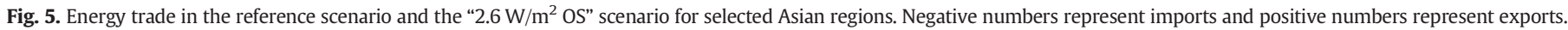


Table 4

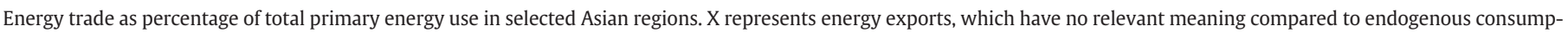
tion in a region.

\begin{tabular}{|c|c|c|c|c|c|c|c|c|c|}
\hline & & \multicolumn{4}{|l|}{ reference } & \multicolumn{4}{|c|}{$2.6 \mathrm{~W} / \mathrm{m}^{2} \mathrm{OS}$} \\
\hline & & Coal (\%) & Oil (\%) & N. Gas (\%) & Mod. Bio (\%) & Coal (\%) & Oil (\%) & N. Gas (\%) & Mod. Bio (\%) \\
\hline \multirow[t]{3}{*}{ China } & 2005 & 0 & 40 & 8 & 37 & & & & \\
\hline & 2020 & 4 & 64 & 17 & 46 & 4 & 63 & 17 & 22 \\
\hline & 2050 & 33 & 97 & 87 & 34 & 30 & 97 & 87 & 31 \\
\hline \multirow[t]{3}{*}{ India } & 2005 & 0 & 71 & 23 & 0 & & & & \\
\hline & 2020 & 0 & 86 & 36 & 28 & 0 & 85 & 36 & 20 \\
\hline & 2050 & 3 & 98 & 74 & 52 & 4 & 97 & 77 & 61 \\
\hline \multirow[t]{3}{*}{ Japan } & 2005 & 99 & 100 & 98 & 1 & & & & \\
\hline & 2020 & 100 & 100 & 97 & 29 & 100 & 100 & 97 & 21 \\
\hline & 2050 & 100 & 100 & 84 & 75 & 100 & 100 & 86 & 76 \\
\hline \multirow[t]{3}{*}{ Korea } & 2005 & 80 & 100 & 100 & 37 & & & & \\
\hline & 2020 & 94 & 100 & 100 & 30 & 94 & 100 & 100 & 30 \\
\hline & 2050 & 92 & 100 & 95 & 22 & 94 & 100 & 96 & 61 \\
\hline \multirow[t]{3}{*}{ Indonesia + } & 2005 & $x$ & $\mathrm{X}$ & $\mathrm{X}$ & $X$ & & & & \\
\hline & 2020 & $\mathrm{X}$ & 33 & $\mathrm{X}$ & 90 & $\mathrm{X}$ & 32 & $X$ & 87 \\
\hline & 2050 & 25 & 90 & $\mathrm{X}$ & 7 & 20 & 89 & $\mathrm{X}$ & $X$ \\
\hline \multirow[t]{3}{*}{ South-East Asia } & 2005 & $X$ & 19 & $\mathrm{X}$ & $\mathrm{X}$ & & & & \\
\hline & 2020 & 14 & 66 & $X$ & $\mathrm{X}$ & 13 & 65 & $\mathrm{X}$ & $\mathrm{X}$ \\
\hline & 2050 & 82 & 97 & 39 & 10 & 77 & 97 & 30 & $\mathrm{X}$ \\
\hline
\end{tabular}

imports in the reference scenario, and a further reduction in the "2.6 W/ $/ \mathrm{m}^{2}$ OS" scenario.

Indonesia is currently an exporter of energy, but in the reference scenarios it becomes a net-importer for oil in 2020, and later also for coal. For these fuels the same co-benefit pattern occurs with climate policy. However, there is a drawback from an Indonesian export perspective where a reduced global demand for natural gas result in falling exports in the " $2.6 \mathrm{~W} / \mathrm{m}^{2}$ OS" scenario.

It should be noted that replacing fossil energy imports with bio-energy imports does not necessarily improve energy security, although diversification is as likely as bio-energy is produced in multiple regions and in different regions than currently export fossil energy.

\subsection{Air pollutant emissions}

Another potential co-benefit of climate policy is that the systemic changes induced in the energy system would also reduce emission of air pollutants. Because (urban) air pollution is a major concern in many Asian regions, especially China, this would be a valuable cobenefit of climate policy (Bollen et al., 2009; van Vuuren et al., 2006a).
Table 5 shows the emission of $\mathrm{SO}_{2}, \mathrm{OC} / \mathrm{BC}$, NOx and $\mathrm{CO}$ for the major Asian regions in 2005, and for the reference and " $2.6 \mathrm{~W} / \mathrm{m}^{2}$ OS" scenarios. The emission factors are based on the EDGAR database (European Commission Joint Research Centre (JRC)/Netherlands Environmental Assessment Agency (PBL), 2009) and modelled to converge to the level of present-day high-income countries with increasing GDP per capita (following an Environmental Kuznets Curve) (Stern, 2004; van Ruijven et al., 2008).

In the reference scenario, emissions of most substances fall for China, as a result of air quality policy induced introduction of abatement technologies (i.e. lower emission factors). For India, this is not the case, as the country has lower GDP per capita levels than China, and face a large increase in fossil fuel use over the next decades. Only emissions of $\mathrm{OC} / \mathrm{BC}$ decrease with phasing out of traditional fuels. Indonesia and South-East Asia show a similar pattern as India, with increases in emissions of other air pollutants and reductions in OC/BC. Japanese and Korean emissions decrease in the reference scenario for all pollutants.

In the " $2.6 \mathrm{~W} / \mathrm{m}^{2}$ OS" scenario, emissions of all air pollutants are lower than in the reference scenario. Especially emissions of sulphur are reduced by 43 to $75 \%$ in 2050 compared to the reference scenario, due to a decrease in coal use. Emissions of OC/BC, NOx and CO are less

Table 5

Air pollutant emissions in selected Asian regions in the reference scenario and changes compared to the reference scenario for the "2.6 W/m ${ }^{2}$ OS" scenario.

\begin{tabular}{|c|c|c|c|c|c|c|c|c|c|}
\hline & & \multicolumn{4}{|l|}{ Reference } & \multicolumn{4}{|c|}{$2.6 \mathrm{~W} / \mathrm{m}^{2}$ OS (\% change to reference) } \\
\hline & & Sulphur (Mt SO2/yr) & $\mathrm{OC} / \mathrm{BC}(\mathrm{Mt} / \mathrm{yr})$ & NOx (Mt NO2/yr) & $\mathrm{CO}(\mathrm{Mt} / \mathrm{yr})$ & Sulphur (\%) & $\mathrm{OC} / \mathrm{BC}(\%)$ & NOx $(\%)$ & $\mathrm{CO}(\%)$ \\
\hline \multirow[t]{3}{*}{ China } & 2005 & 41.8 & 7.5 & 28.3 & 149.3 & & & & \\
\hline & 2020 & 62.5 & 6.1 & 42.0 & 159.0 & -11 & -7 & -8 & -6 \\
\hline & 2050 & 22.4 & 1.6 & 24.4 & 52.5 & -53 & -8 & -15 & -8 \\
\hline \multirow[t]{3}{*}{ India } & 2005 & 8.3 & 3.7 & 10.2 & 66.4 & & & & \\
\hline & 2020 & 15.9 & 4.0 & 19.0 & 85.3 & -19 & 0 & -10 & -3 \\
\hline & 2050 & 34.5 & 3.1 & 35.9 & 98.5 & -75 & -9 & -38 & -15 \\
\hline \multirow[t]{3}{*}{ Japan } & 2005 & 1.8 & 0.2 & 2.8 & 8.3 & & & & \\
\hline & 2020 & 1.3 & 0.1 & 2.1 & 5.3 & -3 & -8 & -2 & -3 \\
\hline & 2050 & 0.7 & 0.1 & 1.5 & 3.1 & -44 & -52 & -26 & -12 \\
\hline \multirow[t]{3}{*}{ Korea } & 2005 & 3.4 & 0.3 & 2.2 & 5.1 & & & & \\
\hline & 2020 & 1.9 & 0.2 & 2.1 & 4.3 & -12 & -11 & -8 & -9 \\
\hline & 2050 & 0.7 & 0.1 & 1.3 & 2.2 & -43 & -23 & -16 & -11 \\
\hline \multirow[t]{3}{*}{ Indonesia + } & 2005 & 1.7 & 1.1 & 2.1 & 16.2 & & & & \\
\hline & 2020 & 3.1 & 1.0 & 3.5 & 16.5 & -10 & 0 & -7 & -1 \\
\hline & 2050 & 4.5 & 0.4 & 5.7 & 12.6 & -65 & -15 & -31 & -25 \\
\hline \multirow[t]{3}{*}{ South-East Asia } & 2005 & 4.5 & 2.0 & 5.1 & 33.7 & & & & \\
\hline & 2020 & 4.6 & 2.3 & 6.2 & 36.7 & 0 & 0 & -3 & 0 \\
\hline & 2050 & 7.7 & 1.4 & 9.8 & 33.0 & -70 & -23 & -39 & -27 \\
\hline
\end{tabular}


influenced by climate policy: emissions of are reduced by 8 to $40 \%$ across regions in 2050 .

\section{Discussion}

Several uncertainties surround this modelling study, a few of which are highlighted in this section. One field of uncertainty arises from the use of a global model to explore individual world regions. Global models are designed to follow fairly generic patterns that emerge from cross national and regional data, to which individual regions are expected to follow suit. However, historically, large differences between regions can be observed, with which global models have difficulties to comply (see also van Ruijven et al., 2009, 2010). Global models have a purpose of their own, dealing with international energy markets, climate policy and global environmental problems, and these models do hardly account for specific policies in individual regions. Representing countries in the best possible way improves global projections. Hence, confronting the global projections with national insight can improve the quality of projections.

For many indicators, there is a lack of data, or at least good quality data, for instance emissions of greenhouse gases and air pollutants, energy use at detailed sectoral level. As this is likely to be biased by better data availability in industrialised regions, this might obscure trends in future projections. However, (global) models can also help to fill in data gaps with generic assumptions and/or identify data needs for better analysis.

It should be noted that the TIMER energy model does not capture premature capital replacement or lifestyle changes. Although one may assume that premature capital replacement or lifestyle changes (if accounted for), in the real world, could increase the reduction rate and potential, compared to technical constraints included here, socio-economic and political inertia may in fact slow down reductions (see also van Vuuren et al., 2010).

Finally, the mitigation scenarios in this paper do not account for emission trading, as all analyses have been carried out using a globally uniform carbon tax. However, different obligations for emission reductions might emerge from effort sharing approaches, and the difference between allowances and actual emissions might be levelled out by emission trade (van Ruijven et al., in press; van Vliet et al., 2009; van Vuuren et al., 2009) The mitigation costs in developing countries could be partly financed through their own resources, and partly through multilateral public or international funding.

\section{Conclusion}

Based on the analysis of the IMAGE scenarios for the Asian Modelling Exercise, we can draw the following conclusions:

- Asia plays a key role in future global greenhouse gas emission. The Asian regions looked at in this paper currently account for $36 \%$ of the global energy-related $\mathrm{CO}_{2}$ emissions. As a result of rapid economic growth in the Asian regions, the share in global emissions increases towards 50\% in 2030 in the reference scenario. This also implies that reducing Asian emissions will be an important element of any mitigation scenario meeting the $2{ }^{\circ} \mathrm{C}$ target.

- The potential for emission reduction potential varies between regions, but amounts in 2050 generally between 20 and 40\% below 2005 levels for developing regions and 65-85\% below 2005 levels in industrialised regions in the " $\mathrm{CO}_{2}$ Price $\$ 50$ (5\% p.a.)" scenario. Regions that are expected to have a rapid economic growth in the next decades compared to historical rates (like India, Indonesia and South-East Asia) have a larger potential for emission reduction than Asian regions where economic growth has been high in the past decade (or in the next 10 years), but with decreasing growth rates (like China and Korea).
- Technology choices in the power sector as response to climate policy are expected to differ clearly between the Asian regions. The large storage capacity for $\mathrm{CO}_{2}$ in India and Indonesia, leads to CCS being an important mitigation option in these regions. In contrast, Korea and India have low-cost potentials for solar/wind. Projections for Japan include a high share of nuclear power, given limitations in domestic energy sources. However, at this point of time the use of nuclear power in Japan has become very unclear. China and South-East Asia show clearly different technology choices in the power sector.

- The recent rapid expansion of fossil fuel based energy infrastructure in China could limit the potential for emission reduction in the next decades. During the last decade, coal-based industry facilities in China have expanded rapidly. Assuming that technologies are only replaced after their normal lifetime, the expected decreased growth in demand in China implies that there are limits to the potential to reduce emissions, as there will be little demand for new facilities. In contrast, in other countries in the region the expected rapid growth in the next decades may provide an opportunity for investment into low or zero carbon technologies.

- There are various connections between climate policy and other environmental issues. These may represent possible risks (indoor air pollution) or synergies (energy security; urban air pollution). The energy system is related to many sustainability problems. As such, tradeoffs and synergies may occur. Climate policy, for instance, could influence household fuel choices as the costs of modern fuels may go up. This could imply that fewer households switch from traditional fuels to modern fuels. This effect can be mitigation through the introduction of subsidies. Many Asian countries are already major importers of fossil energy or could become importer in the near future. Model calculations show that climate policy could improve the energy security situation. Finally, emissions of air pollutants decrease considerably with climate policy. Especially emissions of sulphur reduce up to 45 to $75 \%$ in 2050 , but also $\mathrm{NO}_{\mathrm{X}}$ and $\mathrm{CO}$ are reduced by $15-40 \%$ across regions in 2050 .

\section{References}

Alcamo, J., Kreileman, E., Krol, M., Leemans, R., Bollen, J., van Minnen, J., Schaeffer, M. Toet, S., de Vries, B.J.M., 1998. Global modelling of environmental change: an overview of IMAGE 2.1. In: Alcamo, J., Leemans, R., Kreileman, E. (Eds.), Global change scenarios of the 21st century. Results from the IMAGE 2.1 model. Elsevier Science Ltd, Oxford.

Bollen, J., van der Zwaan, B., Brink, C., Eerens, H., 2009. Local air pollution and global climate change: A combined cost-benefit analysis. Resour. Energy Econ. 31, 161-181.

Boskaljon, W., 2010. Modeling the steel and cement industry. Dept. of Science, Technology and Society, Utrecht University, Utrecht, the Netherlands, p. 76.

Bouwman, A.F., Hartman, M.P.M., Klein Goldewijk, C.G.M., 2006. Integrated modelling of global environmental change. An overview of IMAGE 2.4. Netherlands Environmental Assessment Agency, Bilthoven, The Netherlands.

Calvin, K., et al., 2012. The role of Asia in mitigating climate change: results from the Asia modeling exercise. Energy Economics 34, S251-S260 (this issue).

Carter, T.R., Parry, M.L., Harasawa, H., Nishioka, S., 1994. IPCC Technical Guidelines for Assessing Impacts of Climate Change. IPCC, Geneva.

Daioglou, V., van Ruijven, B.J., van Vuuren, D.P., in review. Residential Energy Use Scenarios for Developing Countries.

de Vries, H.J.M., van Vuuren, D.P., den Elzen, M.G.J., Janssen, M.A., 2001. The TIMER IMage Energy Regional (TIMER) Model. National Institute for Public Health and the Environment (RIVM), Bilthoven, p. 188.

den Elzen, M., Meinshausen, M., van Vuuren, D., 2007. Multi-gas emission envelopes to meet greenhouse gas concentration targets: Costs versus certainty of limiting temperature increase. Glob. Environ. Chang. 17, 260-280.

den Elzen, M., Lucas, P., Vuuren, D., 2008. Regional abatement action and costs under allocation schemes for emission allowances for achieving low $\mathrm{CO} 2$-equivalent concentrations. Clim. Chang. 90, 243-268.

Ekholm, T., Krey, V., Pachauri, S., Riahi, K., 2010. Determinants of household energy consumption in India. Energy Policy 38, 5696-5707.

European Commission Joint Research Centre (JRC)/Netherlands Environmental Assessment Agency (PBL), 2009. Emission Database for Global Atmospheric Research (EDGAR), release version 4.0 .

FAO, 2007. FAOSTAT database collections. (www.apps.fao.org) Food and Agriculture Organisation of the United Nations, Rome.

Hoogwijk, M., Faaij, A., Eickhout, B., de Vries, B., Turkenburg, W., 2005. Potential of biomass energy out to 2100 , for four IPCC SRES land-use scenarios. Biomass Bioenergy 29, 225-257. 
Hosier, R.H., Dowd, J., 1987. Household fuel choice in Zimbabwe : An empirical test of the energy ladder hypothesis. Resour. Energy 9, 347-361.

IEA, 2009. World Energy Outlook 2009. International Energy Agency, Paris.

IPCC, 2007. Climate Change 2007: Synthesis Report. Cambridge University Press, Cambridge.

Leemans, R., Born, G.J., 1994. Determining the potential distribution of vegetation, crops and agricultural productivity. Water Air Soil Pollut. 76, 133-161.

Lucas, P.L., van Vuuren, D.P., Olivier, J.G.J., den Elzen, M.G.J., 2007. Long-term reduction potential of non-CO2 greenhouse gases. Environ. Sci. Policy 10, 85-103.

Meinshausen, M., Raper, S.C.B., Wigley, T.M.L., 2011a. Emulating coupled atmosphereocean and carbon cycle models with a simpler model, MAGICC6 - Part 1: Model description and calibration. Atmos. Chem. Phys. 11, 1417-1456.

Meinshausen, M., Wigley, T.M.L., Raper, S.C.B., 2011b. Emulating atmosphere-ocean and carbon cycle models with a simpler model, MAGICC6 - Part 2: Applications. Atmos. Chem. Phys. 11, 1457-1471.

Neelis, M., Patel, M., 2006. Long-term production, energy consumption and $\mathrm{CO}_{2}$ emission scenarios for hte worldwide iron and steel industry. Copernicus Insitute for Sustainable Development and Innovation, Utrecht, the Netherlands, p. 174.

OECD, 2011. Preliminary documentation of the scenarios for the OECD Environmental Outlook to 2050. OECD, Paris.

Reddy, A.K.N., Reddy, B.S., 1994. Substitution of energy carriers for cooking in Bangalore Energy 19, 561-571.

Schlesinger, M.E., Malyshev, S., Rozanov, E.V., Yang, F., Andronova, N.G., De Vries, B. Grübler, A., Jiang, K., Masui, T., Morita, T., Penner, J., Pepper, W., Sankovski, A., Zhang, Y., 2000. Geographical Distributions of Temperature Change for Scenarios of Greenhouse Gas and Sulfur Dioxide Emissions. Technol. Forecast. Soc. Chang. 65, 167-193.

Stern, D.I., 2004. The Rise and Fall of the Environmental Kuznets Curve. World Dev. 32, 1419-1439.

UN Population Division, 2010. World Population Prospects: The 2010 Revision. United Nations, New York.

Van Meijl, H., Van Rheenen, T., Tabeau, A., Eickhout, B., 2006. The impact of different policy environments on agricultural land use in Europe. Agric. Ecosyst. Environ. 114, 21-38.

van Ruijven, B.J., 2008. Energy and Development - A Modelling Approach. Dept. of Science, Technology and Society, Faculty of Science, Utrecht University, Utrecht, p. 271.

van Ruijven, B.J., Urban, F., Benders, R.M.J., Moll, H.C., van der Sluijs, J.P., van Vuuren, D.P., de Vries, H.J.M., 2008. Modeling Energy and Development: an Evaluation of Models and Concepts. World Dev. 36. van Ruijven, B., de Vries, B., van Vuuren, D.P., van der Sluijs, J.P., 2009. A global model for residential energy use: Uncertainty in calibration to regional data. Energy 35, 269-282.

van Ruijven, B., van der Sluijs, J., van Vuuren, D., Janssen, P., Heuberger, P., de Vries, B., 2010. Uncertainty from Model Calibration: Applying a New Method to Transport Energy Demand Modelling. Environ. Model. Assess. 15, 175-188.

van Ruijven, B.J., Schers, J., van Vuuren, D.P., 2012. Model-based scenarios for rural electrification in developing countries. Energy 38, 386-397.

van Ruijven, B.J., van Vuuren, D.P., de Vries, H.J.M., Isaac, M., van der Sluijs, J.P., Lucas, P.L., Balachandra, P., 2011. Model projections for household energy use in India. Energy Policy 39, 7747-7761.

van Ruijven, B.J., Weitzel, M., den Elzen, M.G.J., Hof, A.F., van Vuuren, D.P., Peterson, S., Narita, D., in press. Emission allowances and mitigation costs of China and India resulting from different effort-sharing approaches. Energy Policy.

van Vliet, J., den Elzen, M.G.J., van Vuuren, D.P., 2009. Meeting radiative forcing targets under delayed participation. Energy Econ. 31, S152-S162.

van Vuuren, D.P., Cofala, J., Eerens, H.E., Oostenrijk, R., Heyes, C., Klimont, Z., den Elzen, M.G.J., Amann, M., 2006a. Exploring the ancillary benefits of the Kyoto Protocol for air pollution in Europe. Energy Policy 34, 444-460.

van Vuuren, D.P., van Ruijven, B.J., Hoogwijk, M.M., Isaac, M., de Vries, H.J.M., 2006b. TIMER 2.0, Model description and application. In: Bouwman, A.F., Hartman, M.P.M., Klein Goldewijk, C.G.M. (Eds.), Integrated modelling of global environmental change. An overview of IMAGE 2.4. Netherlands Environmental Assessment Agency, (MNP), Bilthoven.

van Vuuren, D.P., den Elzen, M., Lucas, P., Eickhout, B., Strengers, B., van Ruijven, B., Wonink, S., van Houdt, R., 2007. Stabilizing greenhouse gas concentrations at low levels: an assessment of reduction strategies and costs. Clim. Chang. 81, 119-159.

van Vuuren, D.P., den Elzen, M.G.J., van Vliet, J., Kram, T., Lucas, P., Isaac, M., 2009. Comparison of different climate regimes: the impact of broadening participation. Energy Policy 37, 5351-5362.

van Vuuren, D.P., Stehfest, E., den Elzen, M.G.J., van Vliet, J., Isaac, M., 2010. Exploring IMAGE model scenarios that keep greenhouse gas radiative forcing below $3 \mathrm{~W} /$ $\mathrm{m} 2$ in 2100. Energy Econ. 32, 1105-1120.

van Vuuren, D., Stehfest, E., den Elzen, M., Kram, T., van Vliet, J., Deetman, S., Isaac, M., Klein Goldewijk, K., Hof, A., Mendoza Beltran, A., Oostenrijk, R., van Ruijven, B., 2011. RCP2.6: exploring the possibility to keep global mean temperature increase below $2{ }^{\circ} \mathrm{C}$. Climatic Change 109, 95-116. 